\title{
PERANCANGAN KONTROL UMPAN BALIK PEMBANGKITAN OZON MENGGUNAKAN KONTROL PROPORSIONAL INTEGRAL
}

\author{
Restu Eka Pramudya *), Trias Andromeda dan Sudjadi \\ Departemen Teknik Elektro, Universitas Diponegoro \\ J1. Prof. Sudharto, SH, Kampus UNDIP Tembalang, Semarang 50275, Indonesia \\ *)restueka0605@gmail.com
}

\begin{abstract}
Abstrak
Pemanfaatan pembersih yang banyak digunakan, seperti klorin, memiliki beberapa kerugian pada efek yang terbatas dalam mengurangi mikroorganisme. Hal ini juga menimbulkan kekhawatiran tentang kemungkinan efeknya terhadap kesehatan. Pada penelitian kali ini tegangan tinggi impuls digunakan sebagai penghasil gas ozon yangmana membutuhkan reaksi dengan oksigen pada reaktor yang telah dirancang. Konsentrasi ozon sebesar $0,02 \mathrm{mg} / \mathrm{l}(\mathrm{ppm})$ dapat bersifat racun bagi Eschericia coli dan Streptococcus facealis. Ozon akan bereaksi dengan protoplasma sel dengan berperan sebagai oksidator. Diterapkanlah kontrol PI (proportional integral) yang memanfaatkan mikrokontroler Atmega16 untuk menghasilkan sinyal kontrol sesuai kebutuhan. Hasil pengujian dilakukan menggunakan metode kontrol terbuka dan tertutup. Nilai setpoint diatur pada nilai $0,06 \mathrm{ppm}$ dengan target rata - rata ozon yang dihasilkan sebesar $0,02 \mathrm{ppm}$. Kontrol terbuka menghasilan nilai terendah pada $0,017 \mathrm{ppm}$ dan $0,066 \mathrm{ppm}$ pada nilai tertinggi dan nilai rata - rata $0,0137 \mathrm{ppm}$ hingga 0,0254 ppm. Kp pada nilai 700 menghasilkan respon terbaik dengan menghasilkan 0,066 ppm untuk nilai tertinggi dengan rata - rata produksi sebesar $0,02002 \mathrm{ppm}$. Nilai variasi Ti pada kontrol PI mengakibatkan adanya perbaikan respon sistem dengan hasil terbaik diperoleh pada nilai $\mathrm{Kp}=550 \mathrm{dan} \mathrm{Ti}=30$ yang menghasilkan $0,133 \mathrm{ppm}$ sebagai niai tertinggi dengan rata - rata 0,0209 ppm selama waktu pengujian.
\end{abstract}

\section{Kata kunci : Ozon, Kontrol PI, Mikrokontroler Atmega16}

\begin{abstract}
Widely used of cleaners, such as chlorine, has some limited effects on reducing microorganisms and raises concerns about the possible effects on health. In this study, impulse high voltage was used as a producer of ozone gas which requires a reaction with oxygen in the reactor. Ozone concentration of $0.02 \mathrm{mg} / 1$ (ppm) can be toxic to Eschericia coli and Streptococcus facealis. Ozone will react with the protoplasm of the cell by acting as oxidize. Proportional integral controller applied that utilizes with Atmega16 microcontroller to produce control signals. The results carried out in openloop and closedloop control. The setpoint is set at a value of $0.06 \mathrm{ppm}$ with an average ozone yield of $0.02 \mathrm{ppm}$. Openloop control yields the lowest at $0.017 \mathrm{ppm}$ and $0.066 \mathrm{ppm}$ at the highest and an average of $0.0137 \mathrm{ppm}$ to 0.0254 ppm. Kp at 700 produces the best response by generating $0.066 \mathrm{ppm}$ for the highest with an average production of 0.02002 $\mathrm{ppm}$. Ti variation values on PI control improved the system response with the best results at $\mathrm{Kp}=550$ and $\mathrm{Ti}=30 \mathrm{which}$ produced $0.133 \mathrm{ppm}$ as the highest value with average of $0.0209 \mathrm{ppm}$ during the test time.
\end{abstract}

\section{Keywords: Ozone, PI Controller, Microcontroller Atmega16}

\section{Pendahuluan}

Perkembangan teknologi pada zaman modern ini tidak hanya bertujuan untuk teknologi itu sendiri, melainkan yang lebih penting adalah untuk kesejahteraan manusia. Ozon merupakan suatu gas yang terbentuk dari tiga atom oksigen yang bersifat sangat reaktif dan lebih tidak stabil dibandingkan oksigen. Ozon merupakan pengoksidasi yang kuat dengan kekuatan oksidasi enam kali kekuatan oksidasi klorin [1]. Karena kapasitas oksidasi yang tinggi dan potensi inaktivasi mikroba, ozon telah mencegah berbagai jenis kerusakan mikroba yang biasanya ditemui pada buah dan sayuran. Jika tidak digunakan dengan benar, ozon dapat menyebabkan beberapa efek merusak pada fisiologi dan kualitas produk seperti kehilangan kualitas sensorik [2]. Untuk penggunaan yang efektif dan aman dalam pengolahan makanan, konsentrasi ozon optimal, waktu kontak dan kondisi perawatan lainnya harus ditetapkan untuk semua produk [3]. Konsentrasi ozon sebesar 0,02 mg/l dapat bersifat racun bagi Eschericia coli dan Streptococcus facealis. Ozon akan bereaksi dengan protoplasma sel dengan berperan sebagai oksidator [4]. 
Pada penelitian kali ini tegangan tinggi impuls digunakan sebagai penghasil gas ozon yangmana membutuhkan reaksi dengan oksigen pada reaktor yang telah dirancang. Salah satu komponen yang sering digunakan untuk menghasilkan pembangkit tegangan tinggi impuls menggunakan flyback sebagai trafo tegangan tinggi yang berfungsi sebagai menaikkan tegangan tegangan rendah menjadi tegangan tinggi. Berdasarkan latar belakang tersebut pada penelitian ini dilakukan perancangan kontrol umpan balik pembangkitan ozon menggunakan kontrol proporsional integral agar besar kecilnya gas yang dihasilkan dapat terkontrol dan sesuai dengan nilai yagn diinginkan. Kontroler proporsional integral dipilih karena merupakan salah satu jenis kontroler yang terkenal cepat, mudah, dan sering digunakan dalam proses industri dan kontrol sistem lainnya. Kontrol PI (Proporsional Integral) berbasis mikrokontroler Atmega16 memanfaatkan nilai penguatan atau gain yang nantinya akan dikombinasikan dengan nilai keluaran hingga terciptalah error sebagai tolak ukur bagaimana respon sistem akan dihasilkan [5]. Sedangkan sensor yang digunakan adalah sensor gas ozon MQ131 sebagai pengukuran kadar ozon dan salah satu faktor nilai respon umpan balik yang dihasilkan dan data yang didapat selanjutnya dapat ditampilkan melalui LCD.

\section{Metode}

Perancangan sistem kontrol kadar ozon menggunakan dua sistem yaitu kontrol terbuka dan kontrol tertutup menggunakan metode proporsional integral untuk mengontrol nilai PWM sebagai masukan rangkaian pembangkit tegangan tinggi dengan kondisi dan keadaan tertentu. Pemograman menggunakan bahasa $\mathrm{C}$ dan ditanamkan pada sebuah mikrokontroler Atmega16. Gambar 1 menunjukan blok diagram sederahana mengenai kontrol ozon pada perancangan sistem.

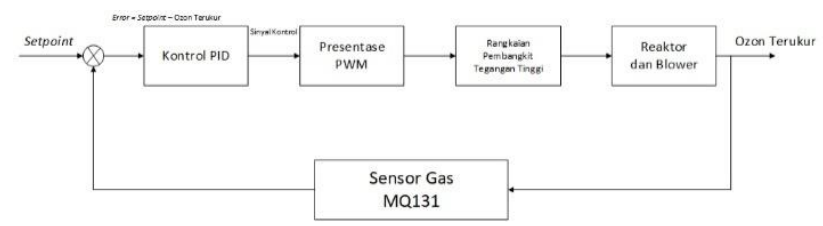

Gambar 1. Diagram blok dasar pengendalian ozon

\subsection{Perancangan Perangkat Keras}

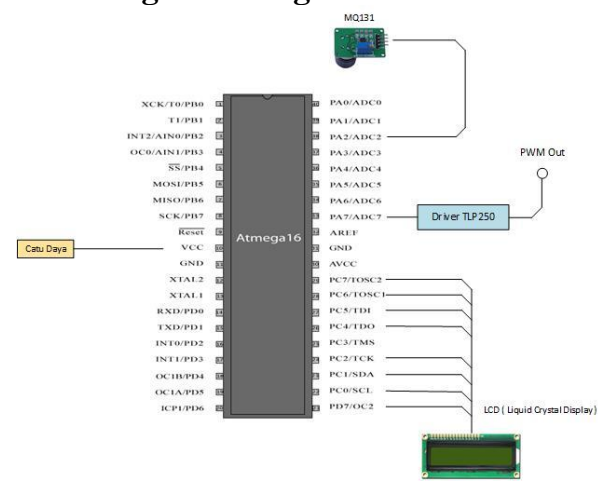

Gambar 2. Diagram blok perancangan perangkat keras
Penjelasan dari masing masing blok perancangan sistem pada Gambar 2 adalah sebagai berikut :

1. Rangkaian sensor MQ131 terdiri dari catu daya 5V DC yang berfungsi sebagai supply dan heater sensor. Sensor berfungsi sebagai pendeeksi keberadaan dan nilai gas ozon yang merupakan hasil dari pembangkitan ozon pada reaktor tegangan tinggi.

2. LCD (Liquid Crystal Display) berfungsi sebagai media tampilan selama proses kontrol berlangsung. Pada sistem ini digunakan layar LCD 16x2.

3. Rangkaian MOSFET driver TLP250 digunakan untuk mengisolasi dan menguatkan sinyal keluaran dari rangkaian kontrol PWM yang dihasilkan oleh mikrokontroler.

4. Mikrokontroler Atmega16 yang berfungsi sebagai pusat pengontrol pada sistem ini diprogram menggunakan bahasa $\mathrm{C}$ embedded.

5. Catu daya berfungsi sebagai supplay untuk keseluruhan sistem. Mikrokontroler dan sensor membutuhkan tegangan 5V DC sedangkan penguat MOSFET driver TLP250 menggunakan input 15V DC.

6. Sinyal PWM keluaran mikrokontroler yang dikuatkan oleh driver kemudian akan terhubung rangkaian Zero Current Switching sebagai cara membangkitkan tegangan impuls.

\subsubsection{Rangkaian Sensor MQ131}

Sensor gas yang digunakan adalah sensor MQ seri 131 buatan Zhengzhou Winsen Electronic Technology dengan model untuk Low Concentration. Sensor ini digunakan untuk mendeteksi keberadaan dan nilai gas ozon yang merupakan hasil dari pembangkitan tegangan tinggi impuls yang sudah dibuat. Berdasarkan datasheet sensor ini membutuhkan tegangan masukan sensor sebesar $5 \mathrm{~V}$ DC dan heater voltage sebesar 5V DC atau AC. Berikut adalah rangkaian pendukung dari sensor gas MQ131.

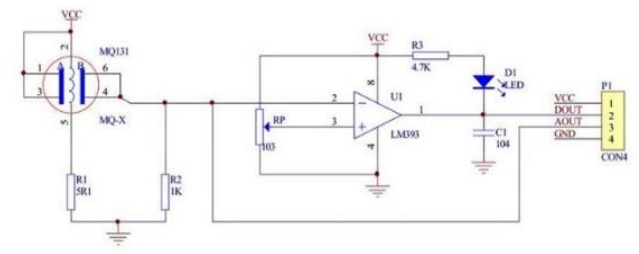

Gambar 3. Rangkaian sensor gas MQ131 [6]

Dari Gambar 3 terlihat bahwa digunakan sebuah keluaran berupa nilai analog dan digital. Digunakan pula resistor R2 sebesar $1 \mathrm{~K} \Omega$ sebagai pembagi tegangan dengan Vout, nilai hambatan ini menjadi nilai RL dalam perhitungan. Besarnya Vout yang diperoleh digunakan sebagai acuan perhitungan nilai ppm yang terbaca oleh sensor ozon. Penguat LM393 digunakan sebagai komponen yang membuat nilai keluaran berupa sinyal digital. Pada perancangan kali ini digunakan keluaran sensor berupa keluaran sinyal analog. Kadar gas ozon yang dihasilkan 
dapat dihitung dengan menerjemahkan grafik karakteristik hambatan keluaran sensor MQ131.

\subsubsection{Perancangan Rangkaian LCD}

Perancangan display untuk menampilkan nilai ADC, Vout, nilai PWM dan kadar ppm. Licuid crystal display (LCD) 2x16 karakter yang digunakan memiliki konfigurasi pin dari LCD dan alokasinya pada port mikrokontroler dapat dilihat pada Gambar 4.

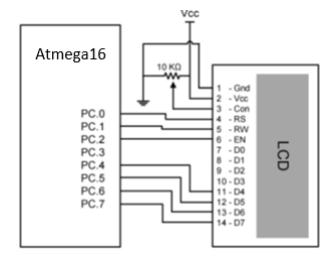

Gambar 4. Alokasi port untuk LCD

Mode transfer data yang digunakan dalam perancangan adalah 4 bit, yaitu dengan hanya menggunakan 4 jalur data teratas DB4-DB7. Pada mode ini, dua nibble data (4 bit teratas dikirim terlebih dahulu kemudian disusul 4 bit terbawah dengan pulsa EN pada masing-masing nibble) dikirim untuk membentuk transfer data penuh 8 bit. Pulsa EN digunakan untuk menginisialisasi transfer data dalam LCD. Potensiometer $10 \mathrm{~K} \Omega$ yang dihubungkan dengan VLCD pada LCD berfungsi sebagai pengatur kontras yang mempengaruhi ketajaman karakter yang tampak pada LCD.

\subsubsection{Perancangan Rangkaian MOSFET Driver TLP250}

Rangkaian MOSFET driver TLP250 digunakan untuk mengisolasi dan menguatkan sinyal keluaran dari rangkaian kontrol mikrokotroler Atmega16. TLP250 dapat digunakan untuk driver MOSFET tegangan tinggi. Rangkaian MOSFET driver TLP250 mendapatkan tegangan 5 VDC dari pembangkit PWM mikrokontroler. Berdasarkan datasheet TLP250, range suplai tegangan yang dibutuhkan TLP250 adalah 10-35 V sehingga digunakan tegangan $15 \mathrm{~V}$ untuk menyuplai TLP250. Sehingga tegangan tersebut akan cukup untuk memicu MOSFET yang digunakan.

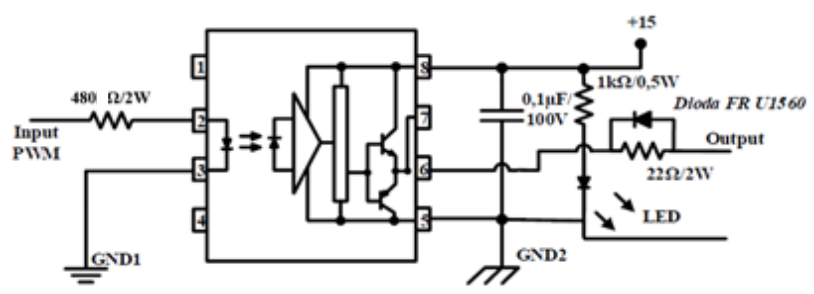

Gambar 5. Rangkaian skematik MOSFET Driver TLP250
Informasi batasan arus photodiode (If) maksimum yang diizinkan terdapat pada datasheet TLP250, yaitu $10 \mathrm{~mA}$, sehingga dapat dihitung nilai resistansi resistor minimum yang diperlukan dengan Persamaan 1 [7].

$$
\begin{aligned}
& \mathrm{Rmin}=\frac{V i n-V f}{I f} \\
& \mathrm{Rmin}=\frac{5-1,8}{10 \times 10^{-3}}=320 \Omega
\end{aligned}
$$

Nilai resistansi minimum yang dibutuhkan adalah $320 \Omega$. Pada penelitian ini dipilih resistor dengan nilai resistansi di atas $320 \Omega$, yaitu $480 \Omega$. Dengan demikian, nilai If akan berubah.

$$
\begin{aligned}
& \text { Rmin }=\frac{5-1,8}{I f} \\
& \text { If }=\frac{5-1,8}{\mathrm{Rmin}}=\frac{5-1,8}{480}=6,6 \mathrm{~mA}
\end{aligned}
$$

Dengan demikian, nilai If diperoleh sebesar 6,6 mA. Hal tersebut tidak menjadi masalah karena dengan nilai If 6,6 mA, TLP250 dapat berfungsi dengan baik.

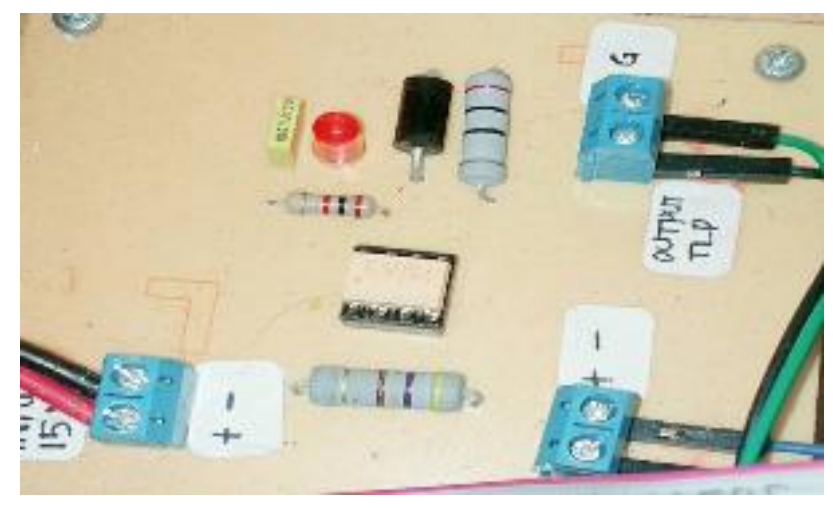

Gambar 6. Realisasi rangkaian MOSFET Driver TLP250

\subsection{Perancangan Perangkat Lunak}

Pemrograman mikrokontroler Atmega16 dapat dilakukan dengan menggunakan bahasa assembly dan C. Perancangan perangkat lunak penelitian ini digunakan bahasa C dengan kompiler CodevisionAVR versi 2.05.3. Secara umum, perancangan perangkat lunak pada mikrokontroler Atmega16 terdiri atas :

1. Perancangan Program Utama

2. Inisialisasi I/O Register dan Variabel

3. Program Pengambilan Data Sensor MQ131

4. Program Tampilan LCD $2 \times 16$

5. Program pembangkitan frekuensi dan PWM

6. Program Kontrol Terbuka dan Kontrol Proporsional Integral 


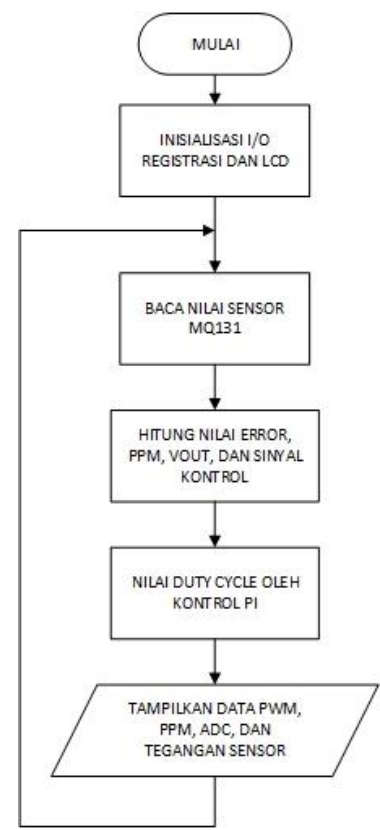

Gambar 7. Diagram Alir Program Utama

Diagram alir program utama pada Gambar 7 dapat dilihat bahwa program dimulai dengan melakukan inisialisasi I/O port dan inisialisasi variable pada mikrokontroler. Setelah inisialisasi, program akan mulai menjalankan pembacaan sensor dan menghitung besarnya Vout sensor yang selanjutnya akan dikonversi menjadi nilai hambatan. Kemudian dari perbandingan nilai hambatan akan diperoleh besarnya nilai ppm. Nilai ppm ini akan menentukan besarnya nilai sinyal kontrol yang akan digunakan untuk mengatur besarnya nilai PWM yang dihasilkan secara otomatis. Berbeda dengan kontrol terbuka yang hanya memberikan nilai masukan secara manual tanpa dipengaruhi oleh nilai keluaran yang dihasilkan.

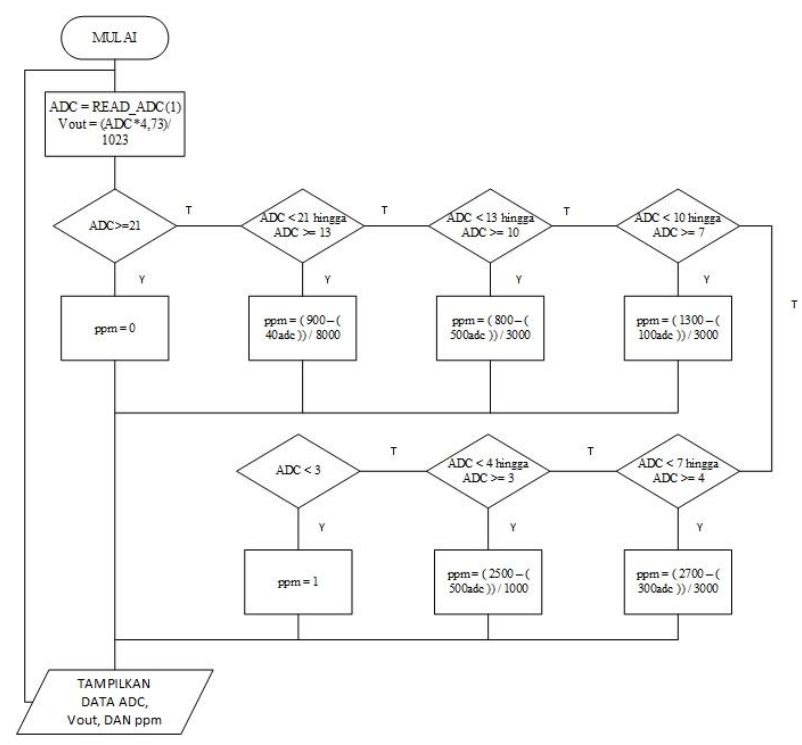

Gambar 8. Diagram alir pembacaan sensor MQ131
Pengambilan data ADC dilakukan untuk memperoleh nilai tegangan keluaran sensor, yang kemudian diolah untuk mendapatkan nilai kadar ppm gas ozon. ADC yang digunakan sebesar 10 bit dan menggunakan AVCC sehingga menggunakan tegangan referensi sebesar $5 \mathrm{~V}$. Nilai ADC dibaca dengan waktu tunda $100 \mathrm{~ms}$, hal ini dikarena perubahan dan pembacaan gas ozon yang tidak stabil dan diperlukan pengolahan data terus menerus.

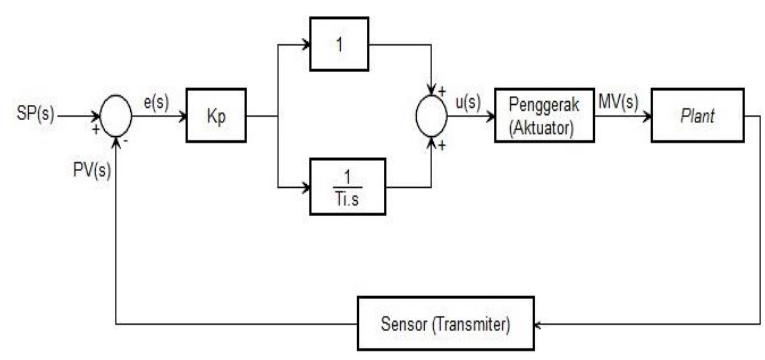

Gambar 9. Diagram blok kontrol PI [5]

Penambahan blok integrator pada dasarnya dimaksudkan untuk menggantikan sinyal bias yang berfungsi untuk menghilangkan ess. Selama masih terdapat error maka kontrol PI akan selalu membesar dan mengecil agar dapat menghasilkan keluaran sesuai dengan referensi. Pemilihan parameter waktu atau konstanta integral pada kontrol PI secara langsung akan mempengaruhi karakteristik keluaran plant yang dikontrol. Jika kedua parameter kontrol PI (Kp dan Ti) dipilih secara tepat, maka respon keluaran yang dihasilkan akan sesuai dengan referensi. Pembesaran atau pengecilan nilai parameter PI dapat menyebabkan respon menjadi lambat atau berosilasi.

Kontroler Proporsional memiliki hubungan antara sinyal keluaran (Output) dengan sinyal kesalahan (Error), dirumuskan sebagai berikut: $\mathrm{m}(\mathrm{t})=\operatorname{Kp} \cdot \mathrm{e}(\mathrm{t})$

dimana: $\mathrm{m}(\mathrm{t}) \quad=$ Sinyal keluaran (Output signal)

$\mathrm{Kp}=$ Konstanta penguatan dari kontroler proporsional

$\mathrm{e}(\mathrm{t}) \quad=$ Sinyal kesalahan $($ Error signal $)$

Untuk sebuah modul kontrol PID, kontrol PI dapat diperoleh dengan cara men-setting nilai gain (waktu) derivatif sama dengan nol, atau secara matematis dapat ditulis seperti pada (3).

$u(t)=K p\left(e(t)+\frac{1}{T i} \int_{0}^{t} e(t) d t\right)$

Dalam kawasan laplace, (3) tersebut dapat direpresentasikan menjadi,

$u(s)=K p\left(e(s)+\frac{1}{\text { Ti.s }} \cdot e(s)\right)$

Dimana Kp merupakan konstanta $\mathrm{P}$ dan Ti merupakan waktu I. Konstanta I dapat diperoleh dengan mengalikan konstanta $\mathrm{P}$ dengan invers $\mathrm{Ti}$. 


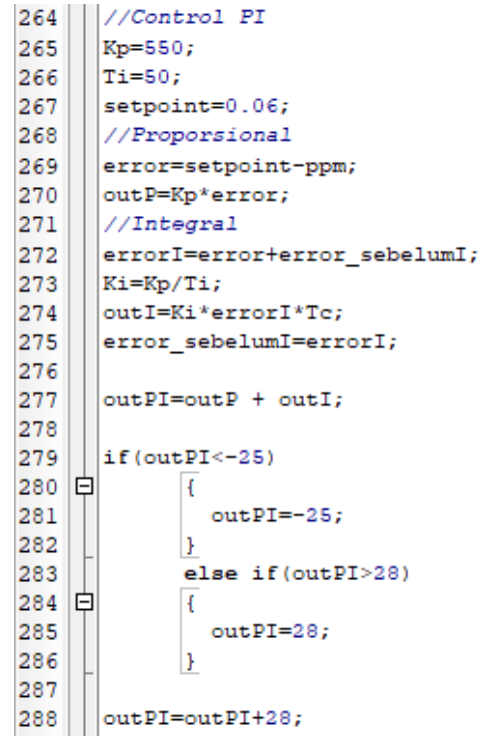

Gambar 10. Realisasi kontrol PI pada pemrograman

3. Hasil dan Analisis

3.1 Pengujian Driver TLP250

Tabel 1. Hasil pengujian nilai PWM dan frekuensi Driver TLP250

\begin{tabular}{ccccc}
\hline No & $\begin{array}{c}\text { PWM pada } \\
\text { Tampilan LCD } \\
(\%)\end{array}$ & $\begin{array}{c}\text { PWM Terukur } \\
\text { Osiloskop }(\%)\end{array}$ & $\begin{array}{c}\text { Selisih } \\
(\%)\end{array}$ & $\begin{array}{c}\text { Frekuensi } \\
(\mathrm{kHz})\end{array}$ \\
\hline 1. & 5 & 5,8 & 0,8 & 24,116 \\
2. & 10 & 10,6 & 0,6 & 24,116 \\
3. & 20 & 20,2 & 0,2 & 24,116 \\
4. & 30 & 30,1 & 0,1 & 24,116 \\
5. & 40 & 39,4 & 0,6 & 24,116 \\
6. & 50 & 49,0 & 1,0 & 24,116 \\
7. & 60 & 58,7 & 1,3 & 24,116 \\
8. & 70 & 68,9 & 1,1 & 24,116 \\
9. & 80 & 77,7 & 2,3 & 24,116 \\
10. & 90 & 87,4 & 2,6 & 24,116 \\
& & Jumlah & 10,6 & \\
\hline
\end{tabular}

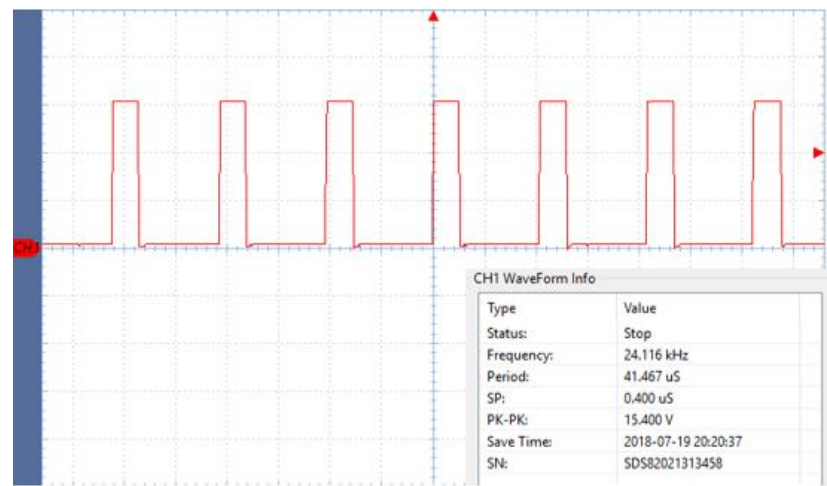

Gambar 11. Sinyal PWM duty cycle 25\% frekuensi 24,116 kHz Driver TLP250

Rata - rata 1,06\% yang didapatkan realtif kecil sedangkan nilai frekuensi hasil mikrokontroler terbaca konstan dan tetap pada nilai $24,116 \mathrm{kHz}$. Penguatan sinyal terbukti dengan melihat tegangan peak to peak yang dihasilkan oleh mikrokontroler dan driver memiliki kenaikan perubahan tegangan yaitu 15 VDC mengikuti supply driver dengan nilai duty cycle dan frekuensi yang masih sama.

\subsection{Pengujian Sistem Kontrol Terbuka}

Pengujian sistem kontrol terbuka dilakukan dengan cara tanpa memberikan nilai setpoint maupun nilai gain. Pengujian ini dilakukan dengan melihat bagaimana pengaruh keluaran terhadap nilai sinyal kontrol yang diberikan tanpa ada perubahan.

Tabel 2. Perbandingan sinyal kontrol terhadap gas ozon

\begin{tabular}{ccccc}
\hline No. & PWM $(\%)$ & $\begin{array}{c}\text { Kadar Ozon } \\
(\mathrm{ppm})\end{array}$ & $\begin{array}{c}\text { Rata - Rata } \\
\text { Ozon }(\mathrm{ppm})\end{array}$ & $\begin{array}{c}\text { Vout } \\
(\mathrm{kV})\end{array}$ \\
\hline 1. & 2,5 & 0,017 & 0,0137 & 2,52 \\
2. & 10 & 0,017 & 0,0152 & 2,92 \\
3. & 20 & 0,027 & 0,0162 & 4,35 \\
4. & 30 & 0,037 & 0,0216 & 5,68 \\
5. & 40 & 0,037 & 0,0221 & 5,74 \\
6. & 50 & 0,037 & 0,0243 & 6,01 \\
7. & 60 & 0,042 & 0,0216 & 6,12 \\
8. & 70 & 0,066 & 0,0254 & 6,31 \\
\hline
\end{tabular}

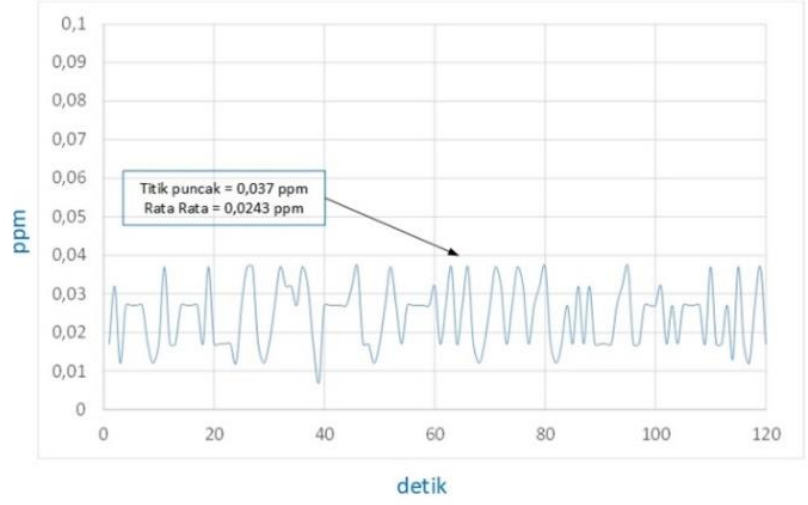

Gambar 12. Respon sistem kontrol terbuka saat input referensi $=\mathbf{5 0} \%$

Berdasarkan pengujian kontrol terbuka yang dilakukan didapatkan nilai gas ozon yang tidak konstan, hal ini dapat dikarenakan sifat gas yang memang cepat sekali hilang sehingga membutuhkan waktu pembacaan yang cepat. Semakin besar nilai referensi input maka akan menghasilkan nilai ozon dan nilai rerata yang semakin besar berbanding lurus dengan nilai referensi.

Hal ini dikarenakan semakin besar nilai PWM yang diberikan maka akan berdampak pada besarnya tegangan tinggi yang dihasilkan, sehingga pada reaktor ozon terbentuk korona dan medan yang semakin besar. Maka dari itu saat gas oksigen dihembuskan maka ozon yang terbentuk akan semakin besar pula. Pada beberapa percobaan terdapat nilai ozon yang kurang lebih sama. 
Tabel 3. Perbandingan nilai ozon dan ADC

\begin{tabular}{ccc}
\hline No. & Kadar Ozon $(\mathrm{ppm})$ & ADC \\
\hline 1. & 0,017 & 19 \\
2. & 0,017 & 19 \\
3. & 0,027 & 17 \\
4. & 0,037 & 15 \\
5. & 0,037 & 15 \\
6. & 0,037 & 15 \\
7. & 0,042 & 14 \\
8. & 0,066 & 12 \\
\hline
\end{tabular}

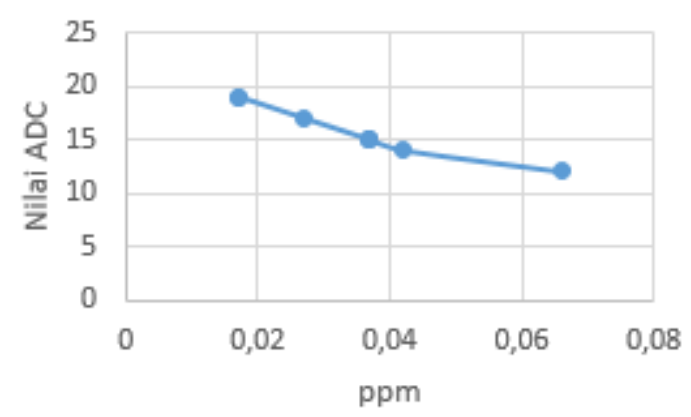

Gambar 13. Grafik hubungan keluaran gas ozon dan nilai ADC

Dari Tabel 5 dan Gambar 13 yang ditunjukan oleh grafik, terlihat bahwa semakin besar nilai gas ozon yang terukur maka nilai ADC akan semakin mengecil. Hal ini berhubungan dengan tegangan keluaran yang dihasilkan oleh sensor dimana pada datasheet penggunaan sensor telah dikatakan bahwa semakin besar nilai ozon yang diukur maka konduktivitas sensor akan mengecil dan nilai hambatan akan semakin membesar. Oleh karena itu dapat dikatakan bahwa pembacaan sensor gas ozon telah terbukti sama dan benar dengan apa yang tertera pada datasheet mengenai penggunaan sensor yang telah dijelaskan pada bab sebelumnya.

\subsection{Pengujian Sistem Kontrol Tertutup}

Pada pengujian yang dilakukan, penalaan parameter proporsional dan integral dilakukan dengan menggunakan metode trial and error, yaitu dengan melakukan variasi nilai parameter Kp dan Ti secara acak sehingga didapatkan hasil yang kiranya terbaik. Pengujian ini dilakukan dengan nilai setpoint kadar gas ozon sebesar 0,06 ppm untuk nilai maksimalnya dengan diharapkan mampu memenuhi nilai rata - rata pengujian sebesar 0,02 ppm mengingat nilai ozon yang tidak bisa konstan dan selalu berubah. Ujicoba dilakukan dengan jarak waktu yang sama yaitu dua menit dengan nilai parameter $\mathrm{Kp}$ dan $\mathrm{Ti}$ yang divariasikan pada rentang nilai tertentu.

Tabel 4. Variasi data parameter $\mathrm{Kp}$

\begin{tabular}{cc}
\hline No & $\mathrm{Kp}$ \\
\hline 1. & 200 \\
2. & 550 \\
3. & 700 \\
\hline
\end{tabular}

Pemilihan nilai Kp dengan nilai yang besar dikarenakan pada pemrosesan respon sistem memiliki nilai error dengan nilai yang kecil. Sehingga untuk bisa mengimbangi agar tercipta nilai untuk respon sistem yang dapat dikatakan cukup, dibutuhkan nilai yang besar.

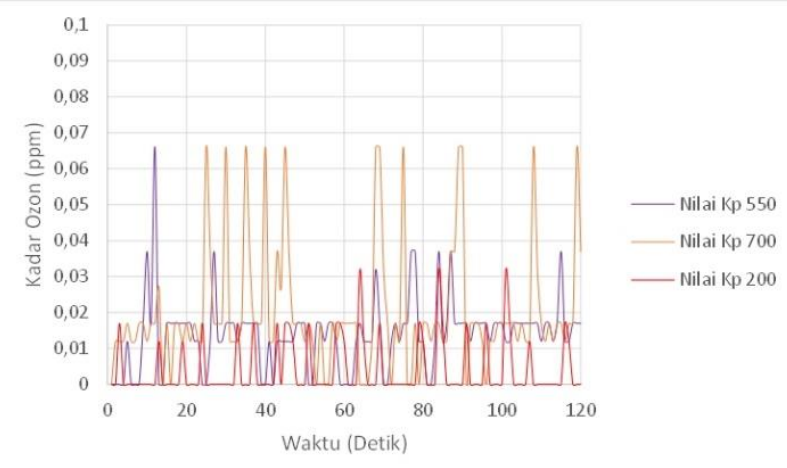

Gambar 14. Hasil perbandingan kadar ozon dengan variasi data parameter $\mathrm{Kp}$

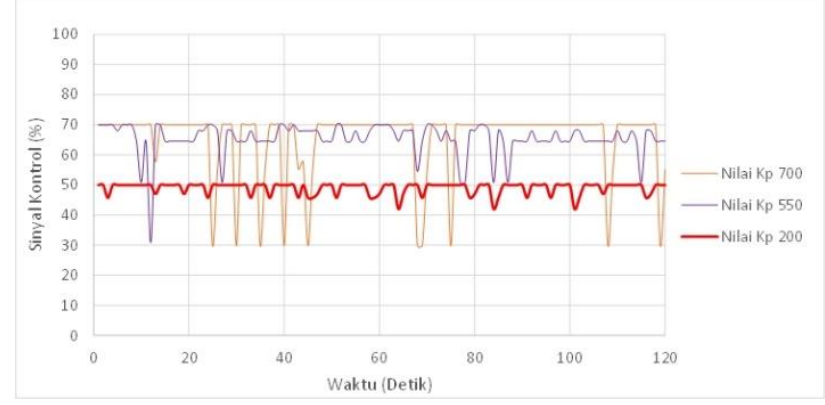

Gambar 15. Hasil perbandingan respon sistem dengan variasi data parameter $\mathrm{Kp}$

Tabel 5. Data pengujian variasi data parameter Kp

\begin{tabular}{cccc}
\hline No & Kp & $\begin{array}{c}\text { Kadar Ozon Tertinggi } \\
(\mathrm{ppm})\end{array}$ & $\begin{array}{c}\text { Nilai Rata - Rata Ozon } \\
(\mathrm{ppm})\end{array}$ \\
\hline 1. & 200 & 0,032 & 0,00400 \\
2. & 550 & 0,066 & 0,01390 \\
3. & 700 & 0,066 & 0,02002 \\
\hline
\end{tabular}

Pada saat parameter Kp diberikan nilai gain 700 , sistem menghasilkan nilai ozon tertinggi yaitu sebesar $0,06 \mathrm{ppm}$ dengan rata - rata produksi pada waktu dua menit sebanyak $0,02002 \mathrm{ppm}$. Sedangkan pada variasi $\mathrm{Kp}=550$, nilai ozon sudah mencapai setpoint namun untuk nilai rata - rata belum dapat memenuhi nilai yang diharapkan. Dan untuk $\mathrm{Kp}=200$ nilai ppm sama sekali belum bisa menyentuh atau mendekati nilai yang di tetapkan.

Untuk nilai $\mathrm{Kp}=200$ sistem hanya mampu menghasilkan sinyal kontrol maksimal sebesar 50\% sehingga sinyal ini tidak cukup besar untuk menghasilkan tegangan tinggi yang dapat menghasilkan nilai ozon sesuai dengan setpoint yang diinginkan. Nilai $\mathrm{Kp}=550$ sudah mampu menghasilkan sinyal kontrol bernilai maksimal untuk mengejar nilai setpoint, namun respon cenderung lebih berada pada titik $65 \%$ untuk sinyal kontrol yang diberikan, 
sehingga untuk pencapaian nilai rata - rata produksi ozon yang diberikan kurang mampu untuk dicapai. Sedangkan untuk nilai $\mathrm{Kp}=700$ sistem cenderung memberikan kontrol pada sinyal maksimal yaitu sebesar $70 \%$ dan merupakan hasil terbaik.

\section{Tabel 6. Variasi data parameter $\mathbf{T i}$}

\begin{tabular}{ccc}
\hline No & $\mathrm{Kp}$ & $\mathrm{Ti}$ \\
\hline 1. & 550 & 10 \\
2. & 550 & 20 \\
3. & 550 & 30 \\
4. & 550 & 50 \\
\hline
\end{tabular}

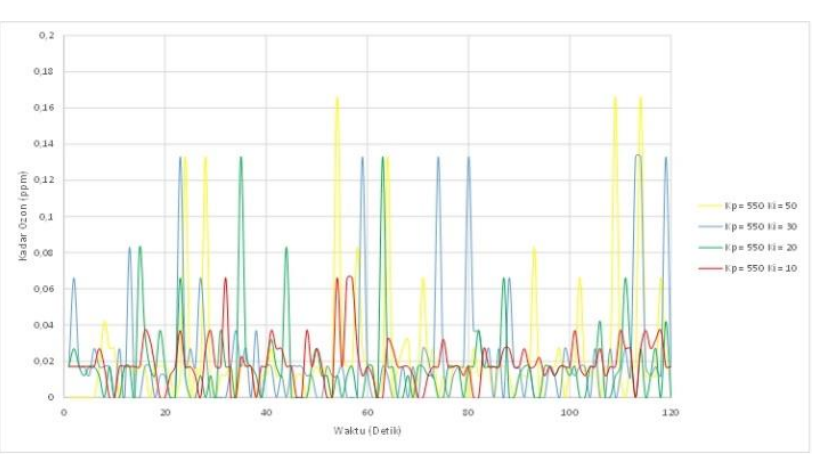

Gambar 16. Hasil perbandingan kadar ozon variasi parameter $\mathrm{Ti}$

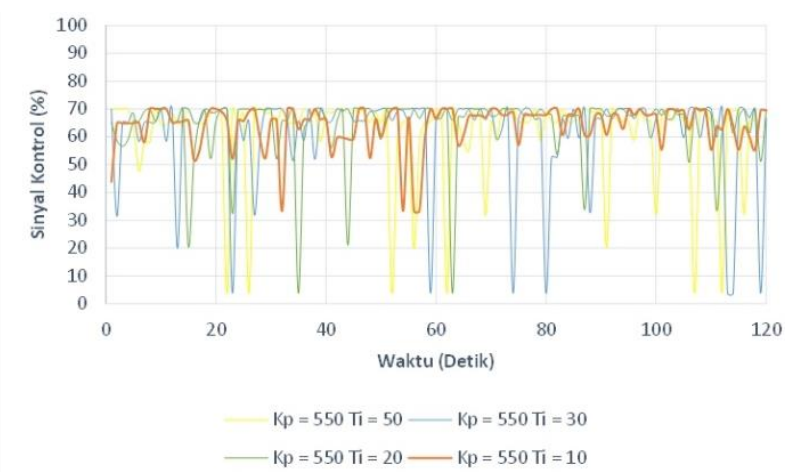

Gambar 17. Hasil perbandingan respon sistem dengan variasi data parameter $\mathbf{T i}$

Tabel 7. Data pengujian variasi data parameter $\mathrm{Ti}$

\begin{tabular}{ccccc}
\hline No & Kp & Ti & $\begin{array}{c}\text { Kadar Ozon Tertinggi } \\
\text { (ppm) }\end{array}$ & $\begin{array}{c}\text { Nilai Rata - Rata } \\
\text { Ozon (ppm) }\end{array}$ \\
\hline 1. & 550 & 10 & 0,066 & 0,0189 \\
2. & 550 & 20 & 0,133 & 0,0165 \\
3. & 550 & 30 & 0,133 & 0,0209 \\
4. & 550 & 50 & 0,166 & 0,0180 \\
\hline
\end{tabular}

Berdasarkan hasil yang didapatkan, dapat diambil kesimpulan bahwa nilai gain terbaik adalah saat $\mathrm{Ti}=30$ dan $\mathrm{Kp}=550$. Pada saat parameter integral diberikan nilai gain tersebut, sistem menghasilkan nilai ozon tertinggi dan rata - rata produksi ozon yang sudah sesuai dengan nilai setpoint dan tujuan yang diinginkan. Kadar ozon sudah dapat mencapai nilai setpoint yang diberikan pada program kontrol tertutup yaitu sebesar 0,06 ppm dengan rata - rata produksi pada waktu dua menit sebanyak 0,0209 ppm.

Sedangkan pada variasi $\mathrm{Ti}=10,20$, dan 50 nilai ozon sudah mencapai setpoint namun untuk nilai rata - rata belum dapat memenuhi nilai yang diharapkan. Respon sistem yang dihasilkan menyesuaikan dengan kebutuhan atau nilai setpoint yang ingin dicapai, hasil sebelumnya diperhitungkan untuk menghasilkan nilai sinyal kontrol yang baru, maka dari itu terlihat bahwa respon semakin mendekati nilai maksimal yaitu $70 \%$ walaupun error yang terjadi semakin mengecil.

\section{Kesimpulan}

Sistem kontrol umpan balik telah berhasil direalisasikan . Hubungan antara sinyal kontrol dan tegangan tinggi yang dihasilkan bersifat berbanding lurus. Terbukti saat sinyal kontrol sebesar 2,5\% akan menghasilkan tegangan sebesar $1,95 \mathrm{kV}$ hingga saat sinyal $70 \%$ dapat mengasilkan 10,05 $\mathrm{kV}$. Nilai ozon terendah berada pada 0,017 ppm dan tertinggi $0,066 \mathrm{ppm}$. Sedangkan rata - rata terendah pada 0,0137 ppm dan tertinggi pada 0,0254 ppm untuk pengujian selama dua menit pada kontrol terbuka. Kadar ozon sudah dapat mencapai nilai setpoint yang diberikan pada program kontrol tertutup proporsional yaitu sebesar $0,066 \mathrm{ppm}$ dengan rata - rata produksi pada waktu dua menit sebanyak 0,02002 ppm dengan $\mathrm{Kp}=700$. Sedangkan pada variasi $\mathrm{Kp}=550$, nilai ozon sudah mencapai setpoint namun untuk nilai rata - rata belum dapat memenuhi nilai yang diharapkan. Dan untuk $\mathrm{Kp}=200$ nilai ppm sama sekali belum bisa menyentuh atau mendekati nilai yang di tetapkan. Hasil terbaik diperoleh pada nilai $\mathrm{Ti}=30$ dengan menghasilkan 0,133 ppm sebagai niai tertinggi dengan rata - rata 0,0209 ppm selama waktu pengujian. Semakin kecil nilai Ti maka perbaikan yang dilakukan akan mempunyai efek yang besar, sehingga mampu memperbesar kemungkinan sistem untuk mencapai nilai yang diinginkan. Kontrol yang dilakukan hanya dapat membuat tegangan tinggi yang dihasilkan cenderung konstan. Namun, ozon yang dihasilkan reaktor cenderung tidak dapat menetap pada satu nilai dan terus berganti sehingga perlu pengambilan nilai rata - rata produksi ozon.

\section{Referensi}

[1]. A. Prasetyo, M. Nur, Z. Muhlisin, and P. Putro, "Reaktor Dielectric Barrier Discharge Plasma Terhadap Konsentrasi Oksigen Terlarut, Kesadahan ," Youngsters Phys. J., vol. 4, no. 3, pp. 237-242, 2015.

[2]. H. Karaca and Y. S. Velioglu, "Ozone Applications In Fruit And Vegetable Processing," Food Rev. Int., vol. 23, no. 1, pp. 91-106, 2007.

[3]. Y. Pratama, A. Adianti, D. Prastiwi, R. Khasanah, and M. Nur, "Penerapan Teknologi Plasma Dengan Memanfaatkan Rancang Bangun Ozone Generator Untuk Pengawetan Cabai Merah ( Capsicum Annuum L .) Guna Mendukung Ketahanan Pangan Nasional," Youngsters Phys. J., vol. 5, no. 2, pp. 69-74, 2016. 
[4]. Balai Penelitian Tanaman Sayuran, "Teknologi Ozonisasi untuk Mencuci Sayuran," Iptek Hortik., no. 10, pp. 1013, 2014.

[5]. I. Setiawan, Kontrol PID Untuk Proses Industri. Jakarta: Elexmedia Komputindo, 2008.

[6]. Liley Tech Store, “DC 5V MQ-131 MQ131," AliExpress, 2018.
[7]. D. D. Ebbing and S. D. Gammon, General Chemistry, 9th ed. Boston, New York: Charles Hartford, 2007.

[8]. Toshiba, "TLP250," vol. 5, pp. 1-7, 2017.

[9]. A. Warsito, Bahan Ajar Komponen Elektronika Daya. Semarang, 2014. 